\title{
埋め込みを有する構造物の非線形応答に関する実験とその解析 EXPERIMENTAL AND ANALYTICAL STUDY OF NONLINEAR DYNAMIC BEHAVIOR OF SOIL-EMBEDDED STRUCTURES
}

\author{
鈴木康䏤*, 内藤幸雄**, 堀越清視*** \\ Yasutsugu SUZUKI, Yukio NAITO and Kiyomi HORIKOSHI
}

\begin{abstract}
Model shaking table tests were conducted to study the dynamic response of an embedded structure which was affected by the plasticity of surrounding soil and dynamic earth pressure acting on embedded walls. A new method for analyzing the dynamic response of an embedded structure was developed. In this method, the material nonlinearity of surrounding soil was handled using the equivalent-linear method, and the geometrical nonlinearity of slide, contact and uplift which occur between a structure and soil was modeled on nonlinear connecting elements.

Simulation was performed for the test results, and the accuracy and reliability of this method were confirmed.
\end{abstract}

Keywords : interaction, earthquake, dynamic analysis, shaking table, geometrical nonlinearity, material nonlinearity

相互作用, 地震, 動的解析, 振動台, 幾何学的非線形, 材料非線形

\section{1.はじめに}

構造物の地震時応答を検討する際に大きな地震力を想 定すると，周辺地盤に関連し，材料非線形性や，構造物 と周辺地盤の境界における摩擦現象（骬り）および土 圧の非対称性にも関連するはく離・浮き上がり等の幾何 学的非線形性が顕著になり，構造物の応答に大きく影響 すると考えられる。したがって，より合理的な耐震設計 を行うために，このような非線形性を総合的に扱い，可 能な限り実際の現象を表現し得る解析手法の確立が望ま れる。

周辺地盤の材料非線形性に関しては, H-D モデル. R-O モデルに代表される一次元せん断振動に関する土 の動力学モデルを用いた弾塑性地震応答解析 ${ }^{11}$, 弾塑 性の履歴曲線を剛性低下率と減衰定数のせん断ひずみに 対する依存性に置き換えた等価線形化手法による地震応 “答解析 ${ }^{2), 31}$ が一般的に行われている。また，女ん断応力 だけでなく圧縮応力の変化も考慮したものとして，拘束 応力の変化による物性の変化を考慮したモデルの提案4) や，そのほかやや塑性の扱いに重点を置いたモデルの提
案宁もなされている。

一方, 本論文で扱う構造物と周辺地盤の境界における 幾何学的非線形性に関しては，岩盤力学や土質力学の分 野において，連続体内の不連続面を表現するために考案 されたジョイント要素6)を，構造物と地盤との接触面に 配し, 有限要素法を用いて動的問題に適用した土岐ら” の研究が挙げられる。また，この手法による解析結果を 実駼結果と比較した研究例として, 構造物の浮き上がり に関する振動台による定常振動実験のシミュレーション を行った渡辺ら ${ }^{8)}$ の研究がある。同様な研究として, 構 造物と地盤の接触面に非線形連結要素9 ${ }^{9}$ 導入し，有限 要素法を用いて, 構造物の浮き上がりに関する振動台に よる加振実験のシミュレーションを行った筆者ら ${ }^{101,11)}$ の 研究がある。これらの研究では，このような非線形要素 を導入することにより，接触面におけるはく離や滑動現 象が考虑でき, 強震時における構造物-地盤系の挙動が 表胃できることが明らかにされている。

材料非線形性と幾何学的非線形性を同時に扱った研究 として土岐ら ${ }^{12)}$ は，はく離や滑動現象に対し，構造物周

\footnotetext{
本論文は，参考文献 20)～24）を中心に加筆しまとめたものである。

* 鹿島建設技術研究所第三研究部 研究員・修士 Research Engineer, Building Structural Engineering Department, Kajima (厂学)

** 鹿島建設技術研究所第三研究部 主任研究員・ 博士 (工学)

*** 鹿島建設技術研究所第三研究部 主管研究貝

Research Engineer, Building Structural Engineering Department, Kajima
Technical Research Institute, Kajima Corp., M.Eng. Senior Research Engineer, Building Structural Engineering Department, Kajima Technical Research Institute, Kajima Corp., Dr.. Eng.

Chief Research Engineer, Building Structural Engineering Department, Kajima Technical Research Institute, Kajima Corp.
} 
辺地盤の降伏が先行したり，あるいは同時に起こる可能 性について検討するために，ジョイント要素に加えて， 周辺地盤を弾性一完全塑性体と仮定し，材料非線形性を 同時に考慮した解析手法を提案し，地盤の降伏が構造物 の地震時挙動ならびに滑動に対する安全性に与える影響 について検討を行うている。また，Vaughan ら51は，地 盤に塑性論的モデルを用い, 構造物と地盤の境界にイン ターフェース要素を用いた解析手法を提案し，制御発破 を用いた実地盤上の模型構造物の加振実験に対するシ ミュレーションを行っている。

材料非線形性と幾何学的非線形性を同時に扱う研究を 進めるうえで，これらの研究の現状は，筆者らの研究の 方向と関連づけて見た場合，以下のようにまとめられる。 a) 滑り・はく離や拘束応力の変化も生ずる複雑な現象 を対象とした動的解析手法に関しては, 実験結果等実際 の現象との対応について研究例も少なく，検討不十分な 面がある。したがって, 現象を正しく理解するうえで実 験結果が必要である。

b) 幾何学的非線形性に関して, 文献 8) における解析 手法の精度を検討するシミュレーションでは, 非線形性 がまだ弱い接地率 $80 \%$ の浮き上がり実験を対象として おり，非線形性がより強くなった場合に関しては今後の 検討が待たれるところである。一方, 文献 10), 11）は, 接地率 $63 \sim 8 \%$ の浮き上がり実験を対象とし, 非線形 連結要素の信頼性・有用性が確認されている。そこで, この手法を材料・幾何学同時非線形の対象にも適用す る。

c) 材料非線形性と幾何学的非線形性を同時に扱った文 献 12）では，周辺地盤の塑性化や局所的な破壊現象を 考虑するため, 周辺地盤を弾性一完全塑性体として扱っ ている。これは, 周辺地盤の局所的な破壊を問題とする 場合には良いが，強震時に広い範囲にわたって地盤が非 線形化する軟弱地盤のような場合には不十分であると考 えられる。

d）実験結果との比較が報告されている文献 5) では, 構造物の速度応答に関し実験とシミュレーションの結果 が示されているが，解析結果の方に高周波成分が多く， 加速度応答を比較する場合にはこの高周波成分による差 異が問題になると考えられる。

e ）材料非線形性に関し，せん断応力だけでなく拘束応 力の変化による物性の変化も考虑した地盤の動的解析手 法は，計算時間が長くかかる傾向にある。

筆者らは上記 a)〜e）の観点から，大地震時に生じる と考えられる非線形現象を対象とした実験的・解析的研 究を行った。

実験としては，振動台による模型実験(3)を行った。こ の実験は，構造物と周辺地盤の境界に生じる幾何学的非 線形性，および周辺地盤の材料非線形性が大地震時には

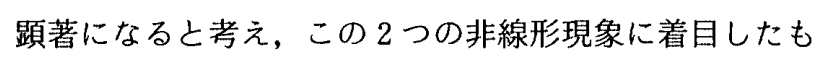
のである。

次に解析手法としては, 周辺地盤の材料非線形性を等 価線形で扱い, 構造物側面に加わる動土圧の主働側（静 止土圧より減少する側）の降伏現象を, 構造物と地盤と の境界におけるはく離現象としてとらえてモデル化し， さらに境界での滑り現象も同時に扱える非線形連結要 素9)を用いた動的解析手法を提案した。

本論では,この解析手法により振動台実験のシミュ レーションを行い, 解析手法の精度と信頼性を確認し, 大地震時に構造物地下部分と地盤との境界や周辺地盤で 生じる非線形現象を扱う解析手法として, 提案しようと するものである。

\section{2. 振動台による模型実験}

\section{1 実験の目的}

以下の諸現象を確認するために，振動台による模型実 験を行った。

a) 埋め込み深さの違いによる構造物の応答の変化

b）入力加速度の違いによる地盤の非線形性の差異が構 造物の応答や構造物側面の動土王に与える影響

c）動土圧の非線形性状

\section{2 実験の概要}

実験は図一1に示す構造物一地盤模型を振動台上に載 せて行った。地盤模型の側方・下方は固定，すなわち振 動台と一体に動く境界とした。これは境界条件を明確に するためである。構造物模型は鋼製でほぼ凮体と見なせ るものであり, シミュレーションを 2 次元モデルで行う ことを考慮し，構造物と地盤の相互作用を多少とも 2 次 元的にするために，長方形平面を採用した。この構造物
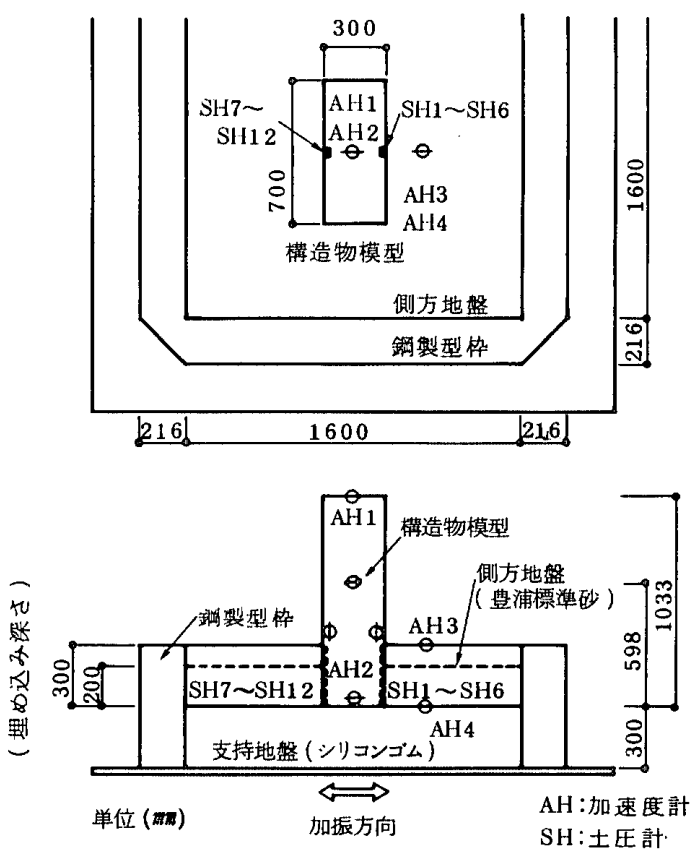

図一1 構造物・地盤模型の概要 
模型を支持地盤模型の中央に設置し，下端を地盤に接着 してその周囲を砂で埋めた。また，実験結果の解积を容 易にするために，材料非線形性は構造物側方地盤だけに 生じさせることとし，支持地盤模型には弾性体と見なせ るシリコンゴムを用いた。なお，このジリコンゴムのヤ ング係数を小さくし，構造物の挙動が側方地盤で支配さ れるようにしている。例えば，側方地盤が無い場合の線 形時の構造物のロッキングが卓越する共振振動数は 3.8 $\mathrm{Hz}$ であるが(0),11)，深さ $20 \mathrm{~cm}$ または $30 \mathrm{~cm}$ の側方地盤 がある場合のロッキングが卓越する共振振動数は 20 $\mathrm{Gal}$ 加振では $10 \mathrm{~Hz}$ 前後である (図一2参照)。側方地 盤には豊浦標準砂を用い，再現性のある実験とするため に振動台上で振動させて楴め固めた。

実験は表一1に示すように, 埋め込み深さと加振加速 度を変えて合計 6 ケース行った。加振は 10 秒間で, 水 平一方向とし, 振動台と試験体各点の加速度の関係が波 形で見た場合にも分かりやすいためスィープ波を用い た。スィープ加振では振動数変化率 $q^{(1), 14)}$ が一定にな るように振動数を 10 秒間で連続的に変化させた。表一1 に示す振動数の変化の範囲は, 構造物模型のロッキング の共振振動数が含まれ，かつ共振する時刻が 10 秒間の 加振時間のうちあまり加振開始早々や終了間際にならな いように設定した。

\section{3 実験結果}

図一2に振動台に対する構造物模型頂部ならびに下部 加速度のフーリエ・スペクトル比を示す。各図の 1 次 ピークは構造物模型のロッキングが卓越する共振振動数 であり，2 次ピークは支持地盤模型の変形が卓越し, 構 造物模型底部が大きく動き，頂部がほとんど動かない モードの共振振動数である。各入力加速度に関して, 埋 め込みが深いほ亡゙ 1 次共振振動数が高くなる傾向にあ る。これは埋め込みによりロッキングに対応する剛性が 增大したためであると考えられる。一方，2次の共振振 動数も埋め込みが深いほじ高くなる傾向がある。これは 支持地盤より側方地盤の剛性が高く, しかも側方の境界 が固定条件であるので，側方地盤の拘束効果が強く表れ たためと考えられる。また，各埋め込み深さに関して， 入力加速度が増加するほぼ 1 次 $\cdot 2$ 次共振振動数共に低 くなる傾向にある。これは側方地盤の非線形性や構造物 側面の動土圧にかかわる非線形性および滑りによるもの と考えられる。

表一1 実験の種類

\begin{tabular}{|c|c|c|}
\hline 埋め込み溧さ $(\mathrm{cm})$ & 加振加速要 (Gal) & スィープ加振振野数 $(\mathrm{Hz})$ \\
\hline \multirow{3}{*}{30} & 20 & \multirow{6}{*}{ 2. $8 \sim 42.0$} \\
\hline & 50 & \\
\hline & 100 & \\
\hline \multirow{3}{*}{20} & 20 & \\
\hline & 50 & \\
\hline & 100 & \\
\hline
\end{tabular}
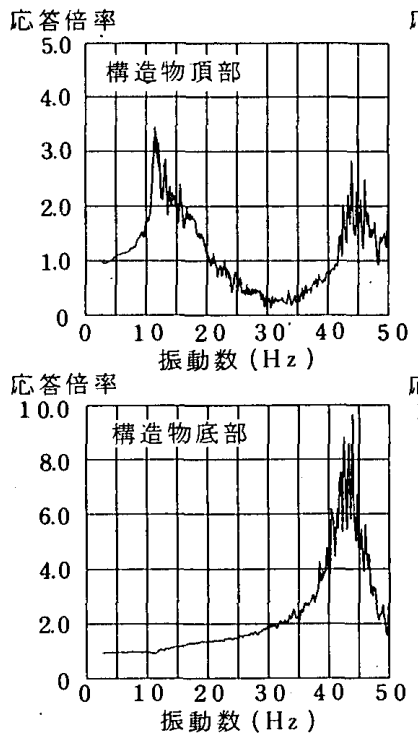

(a) 梁さ $30 \mathrm{~cm}, 200 \mathrm{a} 1$ 加振

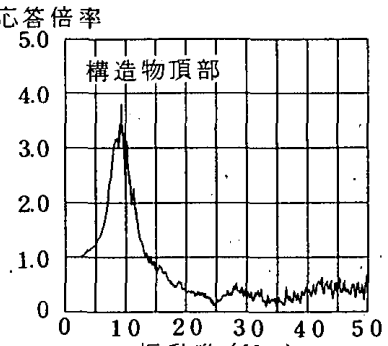

店答倍渔振動数 $\left(\mathrm{Hz}_{2}\right)$

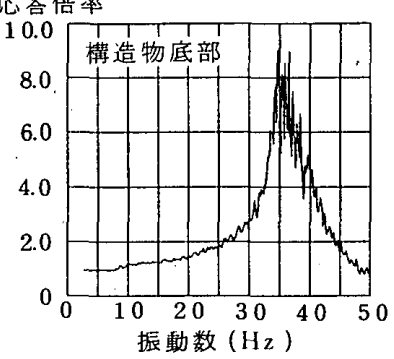

(b) 梁さ $20 \mathrm{~cm}, 20 \mathrm{Gal}$ 加振
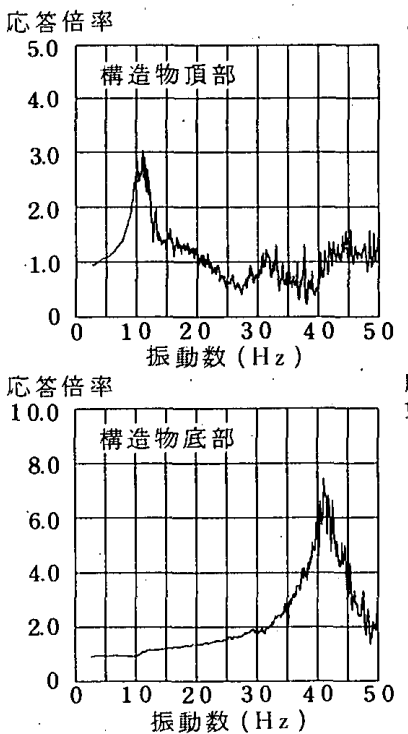

(c) 深さ $30 \mathrm{~cm}, 50 \mathrm{Gal}$ 加振

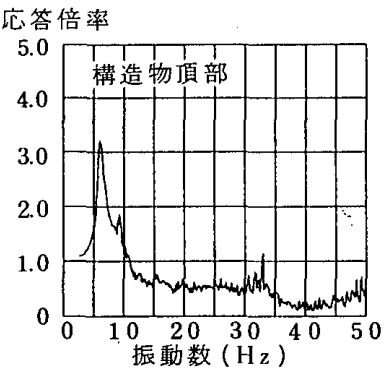

応答倍率

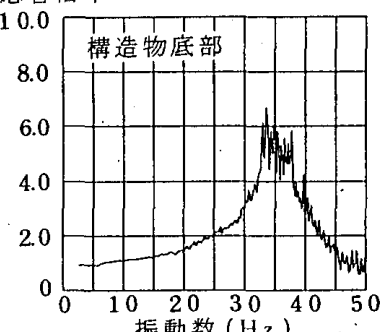

(d) 深さ $20 \mathrm{~cm}, 50 \mathrm{Ga} 1$ 加振

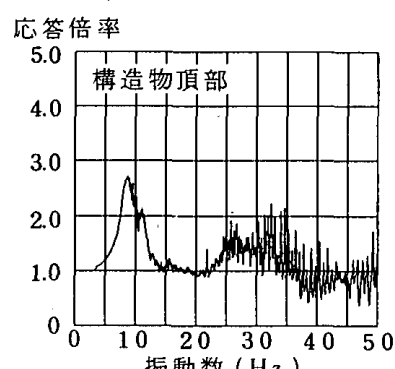

応答倍率振動数 $(\mathrm{Hz})$

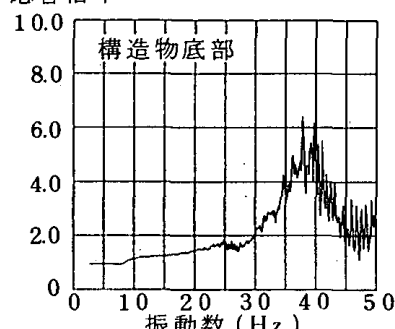

(e) 梁さ $30 \mathrm{~cm}, 100 \mathrm{Ga} 1$ 加振

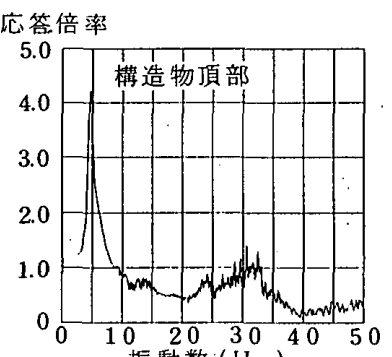

応答倍率

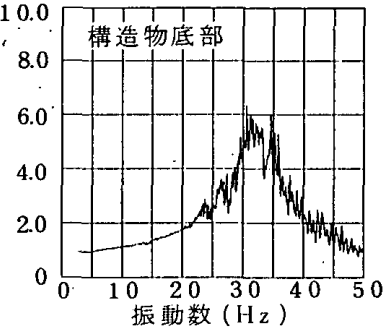

(f) 深さ $20 \mathrm{~cm}, 100 \mathrm{Ga} /$ 加振

图一2 実験結果の振動台に対する構造物模型頂部ならびに底部 加速度のフーリエ・スペクトル比 
次に，側方地盤に生じるひずみが最大となる埋め込み 深さ $20 \mathrm{~cm}, 100 \mathrm{Gal}$ 加振の場合の構造物模型側面の動 土压時刻歴を図一 3 に, $20 \mathrm{~cm}, 100 \mathrm{Gal}$ 加振, ならびに $30 \mathrm{~cm}, 100 \mathrm{Gal}$ 加振の場合の動土圧-相対変位関係を図 -4 に示す。図一 3 および図一 4 の縦軸は，動的な変動 土王成分であり, 図一4 の横軸は, 土圧計設置位置での 構造物模型変位 (構造物模型を剛体と仮定して模型頂部 と底部の加速度記録 AH 1 と AH 2（図一1 参照）を積 分し, 線形補間して求めている）と側方地盤変位（側方 地盤上端と下端の加速度記録 $\mathrm{AH} 3$ と $\mathrm{AH} 4$ (図一1 参 照）を積分し，線形補間して求めている）との相対変位 である。両図より，構造物模型側面に作用する動土王は 主働側（引張側）で明らかに降伏し, 時刻歴や履歴ルー プに平坦部が現れている。これより，振動時における主 働側降伏土王状態に達しているものと推測される。そし て, 動土圧亡相対変位の関係は静的繰返し載荷試験加ら 得られる土圧と変位の関係 ${ }^{(5)}$ と同様に三角形型を示して いる。

これらの結果からこうした現象を扱う解析手法が備 えるべき条件として，以下のことが挙げられる。

a）大地震時に構造物が側方地盤から受ける力を評価す る場合，非線形性を考慮する必要がある。

b）構造物側面が受ける動土圧は，主働側で早い段階か ら降伏現象が見られ, 解析的にもこれを降伏点としで扱 うことが必要である。

なお，主働側で降伏した動土圧時刻歷や履歴ループに 現れる平坦部は，構造物と側方地盤がはく離した場合の 土圧に予想されるものと類似であることから, 以後簡単 のためこの主働側降伏土圧をはく離点と呼ぶことにす る。

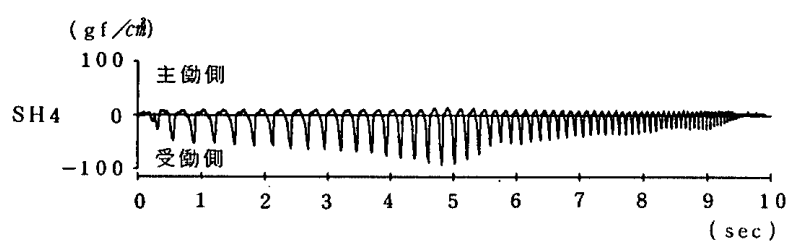

图一3 実験結果の構造物模型倒面の動土圧時刻歴（埋め込み深 さ $20 \mathrm{~cm}, 100 \mathrm{Gal}$ 加振)

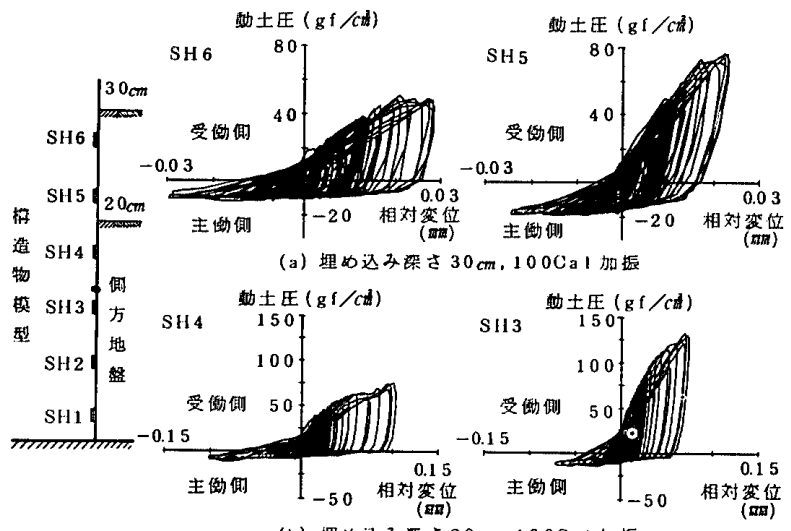

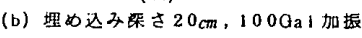

図-4＼cjkstart実験結果の動土圧と相対変位の関係

\section{3. 解析手法}

\section{1 解析手法の概要}

本論では，周辺地盤および構造物と周辺地盤間の非線 形現象を明確にすることに焦点をあてており，それ以外 の諸要因はできるかぎり単純化している。したがってシ ミュレーションにおいても, 連結要素と等価線形による 非線形現象の扱いに重点を置き，構造物と地盤に関して は2 2 次元 FEMによるモデル化を行った。2 次元モデル とした理由は, 計算機の容量・時間の点で現実的である 事, 実験でも現象が多少とも 2 次元的になるよう長方形 平面の構造物模型としている事を考慮したためである。

解析手法の特徵は以下のとおりである。

a) 構造物亡周辺地盤間の滑り・はく離・浮き上がりの 幾何学的非線形性は, 非線形連結要素911111でモデル化す る。

b）周辺地盤の塑性化，すなわち材料非線形性は等価線 形で扱う。なお, 剛性低下が著しく, FEM 要素の形状 と体積がともに変化している場合でも, 等価線形解析の 使用が妥当であり, サイロの振動台実験のシミュレー ションによる確認もなされているとする著者らの論文 ${ }^{161}$ がある。

c）埋め込みがない場合の浮き上がりに関する振動台実 験のシミュレーション ${ }^{100,11}$ により, 幾何学的非線形性に 関しては, 実験と解析の比較・検討が既に行われている。

解析は, 構造物と地盤を 2 次元 FEM 要素でモデル 化し，構造物と地盤の境界面の接点間に図一5に示す軸 ばねと摩擦ばねからなる非線形連結要素を設けて行う。 非線形連結要素は, 構造物と地盤の接触面における状態

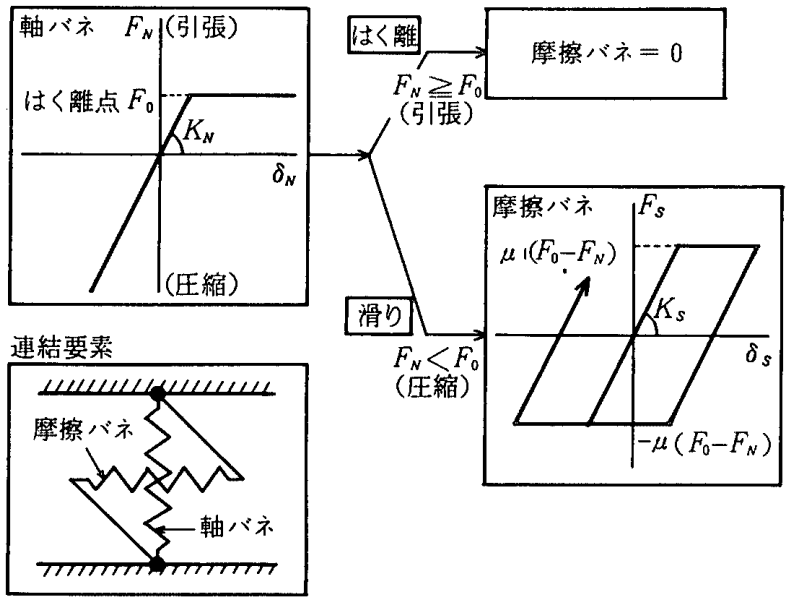

図一5 非線形連結要素のメカニズム

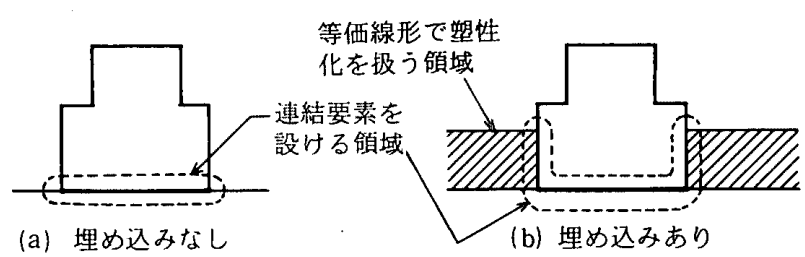

図一6 非線形連結要素を用いた解析モデルの概要 
を，(1)接着・(2)滑り・(3)はく離の3 形態に分けて扱うも のである。こうした連結要素は, 埋め込みのない場合・ ある場合にそれぞれ図一6に示すように，構造物と地盤 の境界節点に設定する。

この解析フローを図一7に示す。まず，非線形連結要 素を線形ば将に置き換えた状態で等価線形解析を行い, 周辺地盤の塑性化の程度を求める。その後, この結果の 要素剛性之诚衰定数を用いて, 幾何学的非線形性を考虑 した時刻歴応答解析を行う。ただし，幾何学的非線形性 はある限界以上の入力によって生じるものなので，入力 が比較的小さい場合には周辺地盤の塑性化のみを考慮す れば十分な場合もある（図一7の*1）。逆に幾何学的非 線形性の影響が大きい場合には，時刻歴応答解析による 周辺地盤の塑性化の程度（ひずみ）が最初の等価線形解 析で仮定した值から大きくずれてくるので，周辺地盤の 塑性化の程度を求め直して再び時刻歴応答解析をする必 要が生じてくる（図一7の*2）。なお，時刻歴応答解析 では，減衰項がバンドマトリックス性を保ち得ることを 考慮し，周辺地盤の塑性化を評価した複素剛性の減衰に 対して等価なレーレー減衰定数を設定し，応答計算を 行っている。

\section{2 解析モデルと諸定数}

埋め込み深さ $30 \mathrm{~cm}$ の場合の解析モデルを図一8に示 す。構造物と地盤は 2 次元 FEM 要素に分割し, 地盤 の側方之下方の境界は実験の状態に合わせて固定端の扱 いとした。加振実験のシミュレーションでは，この固定 端が振動台と同一の動きをするとして応答解析が行われ た。応答解析は自重を考慮しない動的な釣合いに関して 行い，自重による初期応力は非線形連結要素の滑り・は く離の各判定条件の中でのみ考慮した。具体的には，構 造物模型側面では主働側（引張側）の動土圧が静止土圧 と主働側降伏土圧の差（はく離点）を超えた場合にはく 離が生じ, 滑りが生じている場合の摩擦力は静止土圧(本

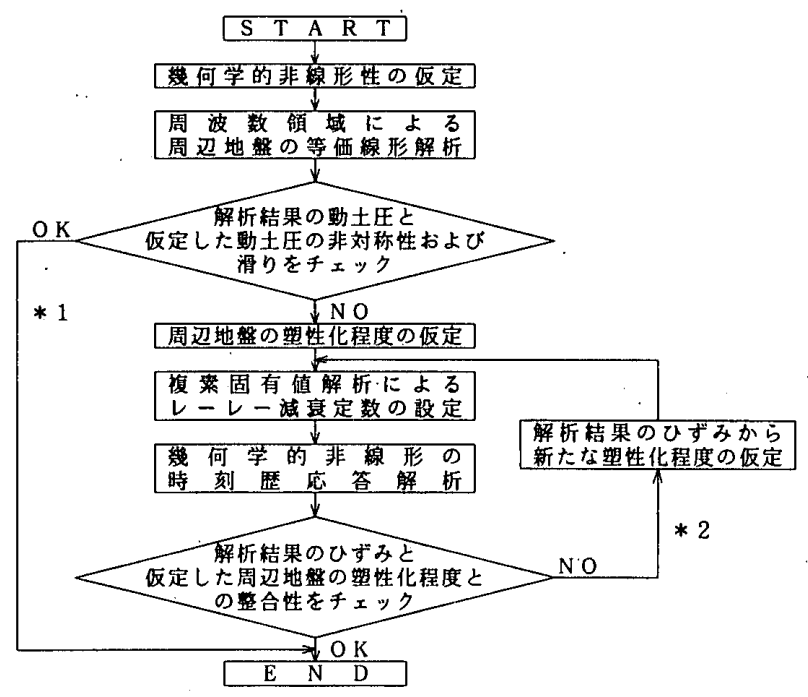

図一7 解析フロー

論の実験では最大測定範囲 $\pm 2 \mathrm{kgf} / \mathrm{cm}^{2}$ の土珐計を用い たため, 静止土圧の測定には不向きな面があったので， 静止土圧＝はく離点土珐として扱った）と動土圧の和に 摩擦係数を乗じた值とした。なお基礎底面には線形ばね を用いた。

解析に用いた定数を表一 2 に示す。構造物模型は，ヤ ング係数がひずみに依存しないとし，各部寸法の詳細測 定の結果に基づき，下端（基礎中心）回りの回転慣性と 重心位置および総重量が模型と解析モデルで一致するよ うに重量を配分した。側方地盤に用いた豊浦標準砂は, 同密度に詰めた砂の PS 検層結果より, 深さ $30 \mathrm{~cm}$ の平 均で $V_{s}=90 \mathrm{~m} / \mathrm{s}$ であった。しかし，実験に用いた砂は 地盤を安定させるために，砂の部分が大きく振動する振 動数 $(40 \mathrm{~Hz})$ で約 1 日振動させて締め固めたため, 剛 性はかなり大きくなっているものと考えられた。文献 17）を参考にして初期せん断弾性係数 $G_{0}$ の変化を考慮 すると，1.5〜2 倍程度大きくなっている可能性があっ た。そこでこの結果と別途実施した固有値解析の結果も 考愿して $G_{0}$ を $V_{s}$ から求めた值の 1.8 倍とした。ただ し，砂の $G_{0}$ は上載応力に大きく依存するため，上載応 力の 0.5 乗に比例し, しかも梁さ $30 \mathrm{~cm}$ の平均で前述 の値となるように（1) 式により梁さごとに変化させた。

$$
G_{0}=1650 \sigma_{v}^{0.5}\left(\mathrm{kgf} / \mathrm{cm}^{2}\right)
$$

ただし， $\sigma_{v}:$ 上載応力 $\left(\mathrm{kgf} / \mathrm{cm}^{2}\right)$

また，せん断弾性係数ならびに減衰定数のひずみ依存性 は図一9に示す標準砂の動的変形試験結果 ${ }^{18)}$ を用いた。

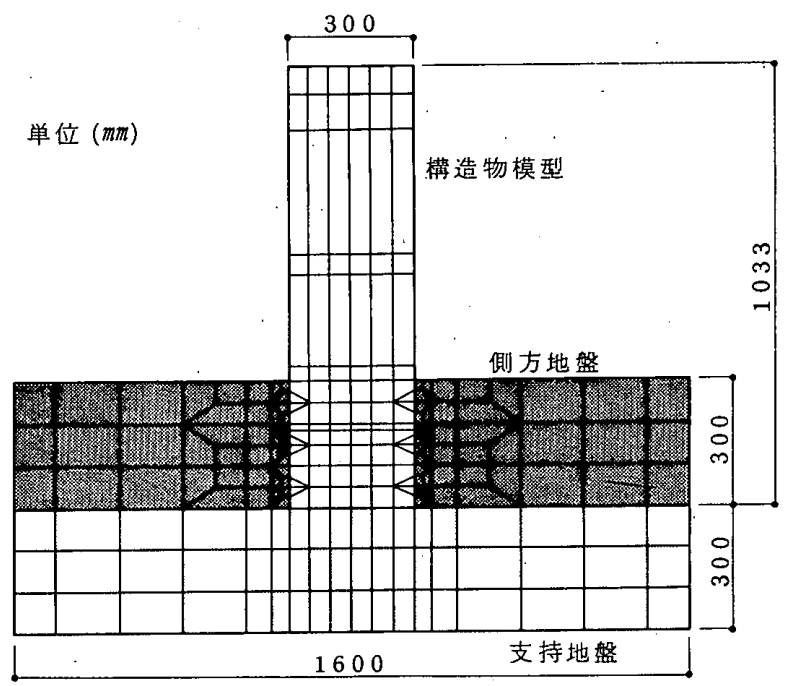

図一8 解析モデル (埋め込み深さ $30 \mathrm{~cm}$ )

表一2 解析に用いた定数一覧

\begin{tabular}{|c|c|c|c|c|c|c|}
\hline 項 & & 目 & 畨造物模型 & 支持地盤 & 側 & 地 盤 \\
\hline 単位体皘重量 & & $\left(\mathrm{gf} / \mathrm{cm}^{3}\right)$ & & 1.555 & & 1.60 \\
\hline ヤング係数 & Eo & $\left(\mathrm{kgf} / \mathrm{cuf}^{2}\right)$ & $2.10 \times 10^{6}$ & 47.0 & (2) & 式より算出 \\
\hline ポアソン比 & $\nu$ & & 0.30 & 0.48 & & 0.325 \\
\hline 減衰定数 & ho & & 0.05 & 0.025 & & 0.005 \\
\hline 䍃 重 量 & $\mathrm{W}$ & $(\mathrm{kgf})$ & 247.6 & - & & \\
\hline 回転惯珄 & I g & $\left(\mathrm{kgf} \cdot \mathrm{cm}^{2}\right)$ & $1.30 \times 10^{n}$ & & & \\
\hline
\end{tabular}


図一9 の横軸は（2）式に示す基準せん断ひずみ $\gamma_{0.5} て ゙$ 正規化している。

$$
\gamma_{0.5}=0.0569 \sigma_{v}^{0.5}(\%)
$$

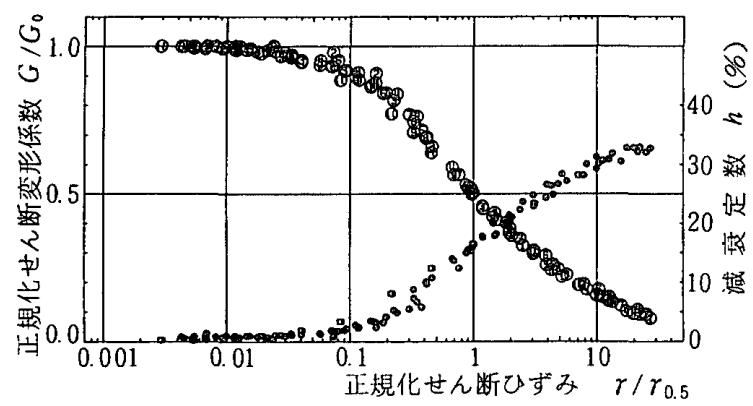

図一9 側方地盤に用いた砂のせん断弾性係数と減衰定数のせん 断ひずみ依存性 ${ }^{18)}$

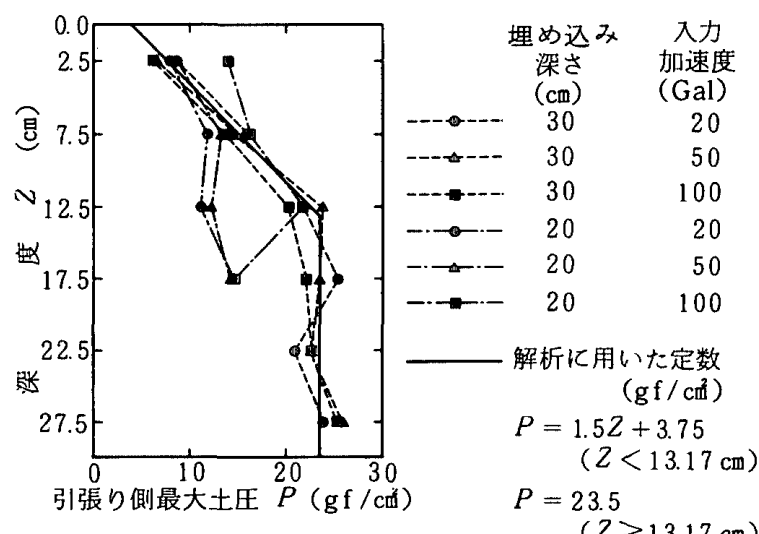

図一10 主働側降伏土圧
したがって，せん断弾性係数のひずみ依存性は，深さ ごとに異なっている。

構造物模型側面の非線形連結要素のばね剛性は, 数值 解析上の安定性を考慮して側方地盤の要素剛性程度に設 定し，その主働側のはく離点は図一4等で得られた降伏 土王を深さの関数とみなして得られた図一-10に示す結 果を用いた。なお，図一10は構造物両側面の值の平均 で示している。

また，鋼製の構造物模型と側方地盤との間の摩擦係数 は，鋼材表面を研摩仕上げしているので，文献 19）に 示されている研摩仕上げしたステンレス鋼と豊浦標準砂 との摩擦係数である 0.1 を採用した。

\section{4. 実倹結果と解析結果の比較}

シミュレーションは，表一1に示した 6 ケースについ て実施した。各ケースについて図一7に示した解析フ ローに従い，等価線形解析と非線形連結要素を用いた解 析を行った。解析結果の内，埋め込み深さ $30 \mathrm{~cm} \cdot 20$ $\mathrm{cm}$ の各々について $50 \mathrm{Gal}$ 加振の場合の構造物模型頂部 と底部の応答加速度時刻歴および構造物模型側面の動土 圧時刻歴を，実験結果・等価線形解析結果・非線形連結 要素を用いた解析結果の順に並べて図一11〜図-14に 示す。また同様のケースについて，振動台に対する構造 物模型頂部と底部加速度のフーリエ・スペクトル比（以 下スペクトル比とする）を，図-15，図-16に示す。 図-11〜図一14に示された構造物頂部の加速度時刻歴

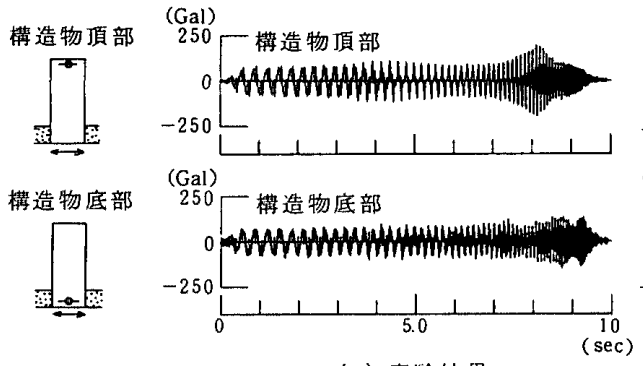

(a) 実験結果

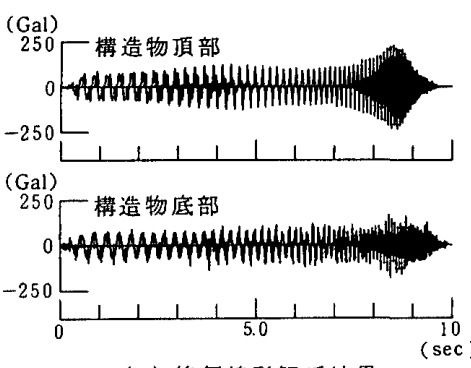

（b）等価線形解析結果

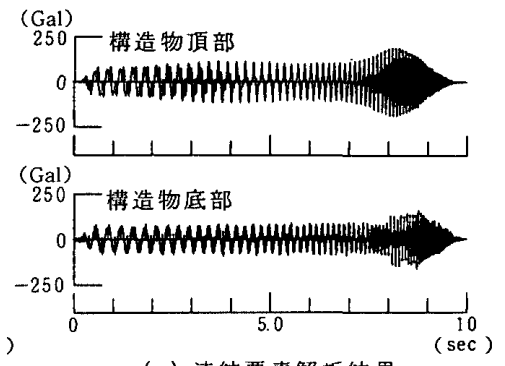

(c) 連結要素解析結果

図一11 応答加速度時刻歴（埋め込み媣さ $30 \mathrm{~cm}, 50 \mathrm{Gal}$ 加振）

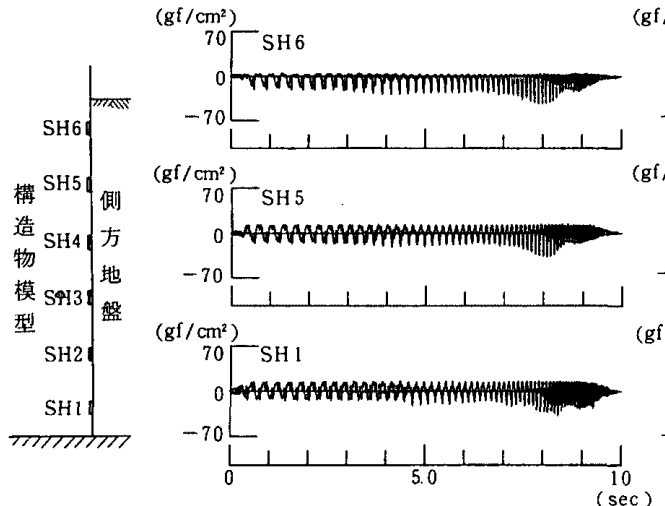

(a) 実験結果

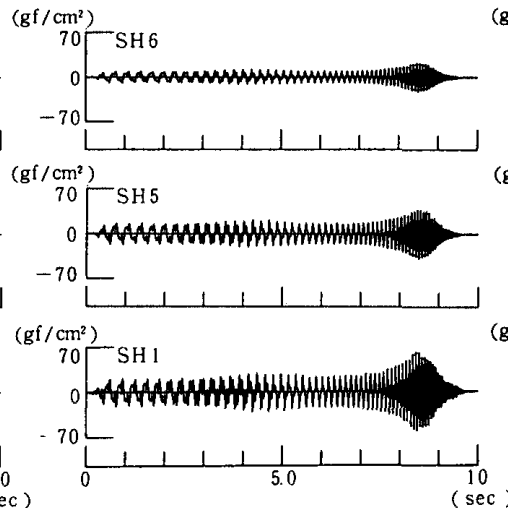

（b）等価線形解析結果

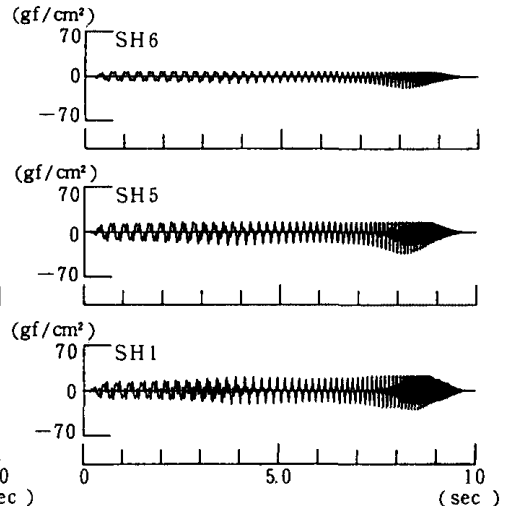

(c) 連結要紫解析結果

図一12 動土圧時刻歴（埋め込み深さ $30 \mathrm{~cm}, 50 \mathrm{Gal}$ 加振） 


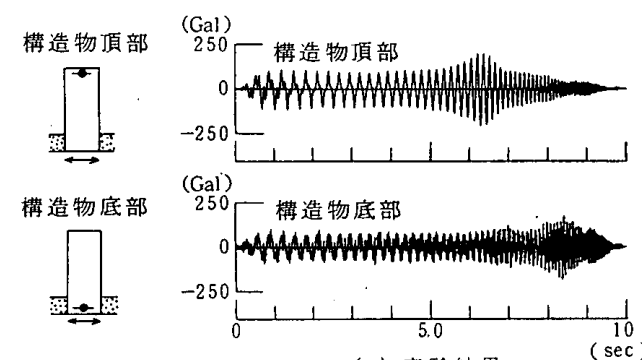

(a) 実験秥果

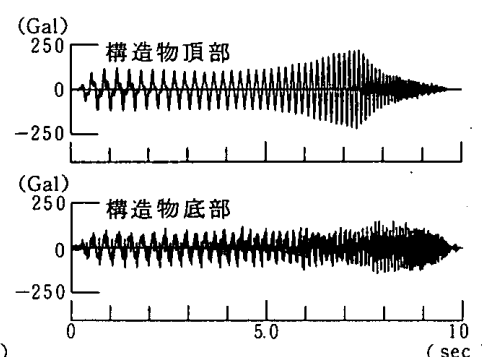

(b) 等価線形解析結果

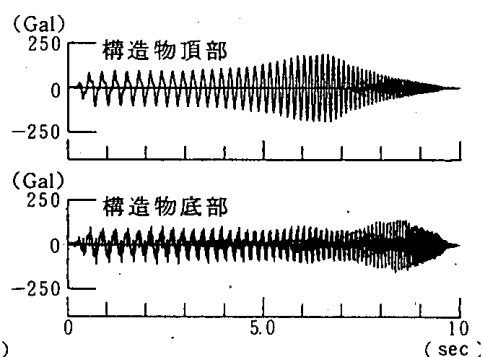

(c) 速結要素解析結果

図一13 応答加速度時刻歴 (埋め込み深さ $20 \mathrm{~cm}, 50 \mathrm{Gal}$ 加振)

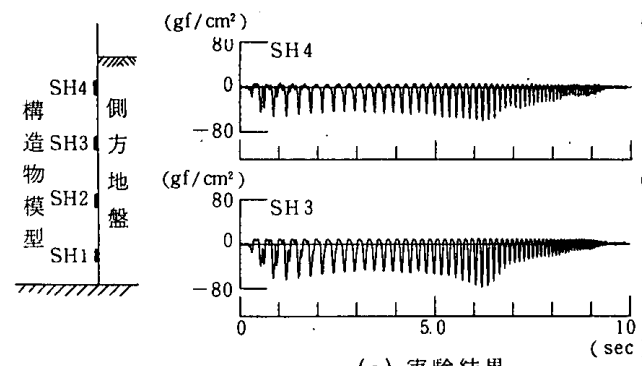

(a) 実験結果

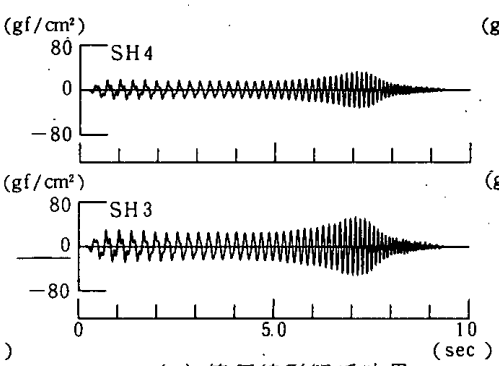

（b）等価線形解析結果

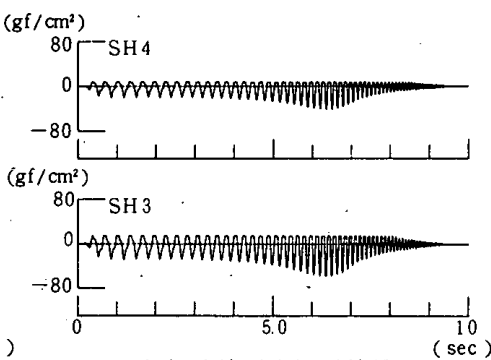

(c) 連結要素解析結果

図一14動土圧時刻歴 (埋め込み深さ $20 \mathrm{~cm}, 50 \mathrm{Gal}$ 加振)
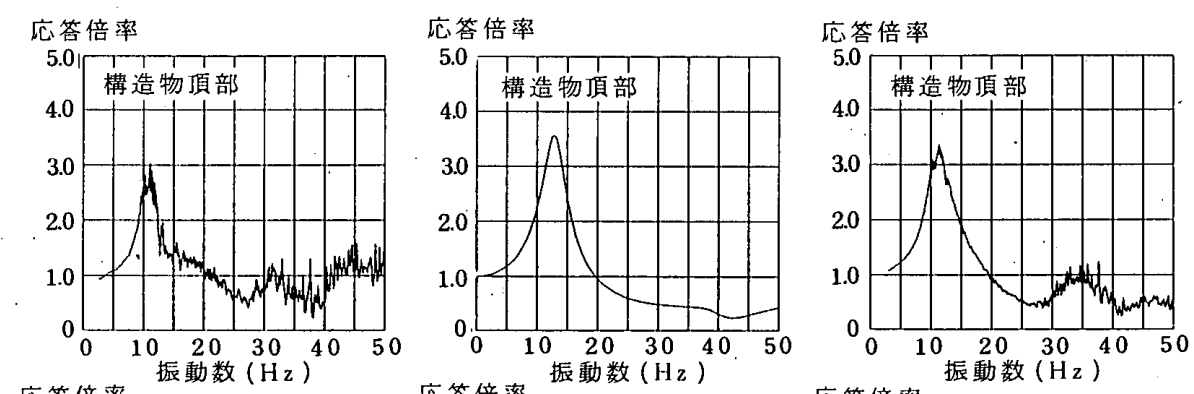

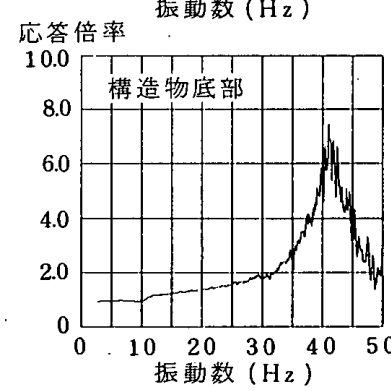

(a) 実験結果

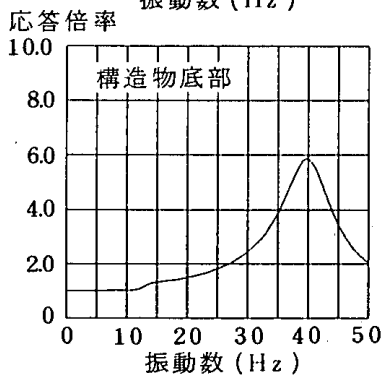

(b) 等洒線形解析結果

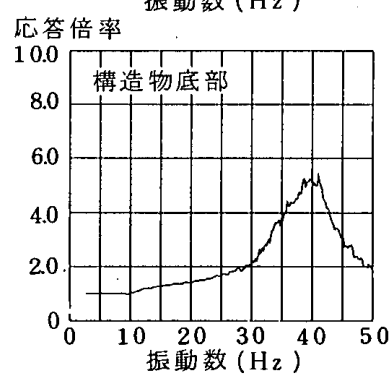

(c) 連結要素解析結果

図一15 振動台に対する構造物模型頂部ならびに底部加速度のフーリエ・スペクトル比 (埋め込み深さ $30 \mathrm{~cm}, 50 \mathrm{Gal}$ 加振)

のピークや土圧時刻歴のピークは, 各ケースにおける構 造物頂部のスペクトル比の低振動数側のピーク（構造物 のロッキングが卓越するピーク）に対応している。

両ケースとも， 2 次の共振振動数である構造物底部の スペクトル比のピークは, 両解析結果とも実験結果と良 く対応しており，2 次のピークのひずみ・変位の範囲で は等価線形化により地盤の剛性を正しく評価しているこ とが分かる。しかし, 等価線形解析結果は, 構造物模型 側面の動土王が受働側 (圧縮) ・主働側（引張り）の両 方に効くことおよび滑りが考虑されていないことから， ロッキングが卓越する共振振動数が実験結果よりも高く
なっている。これに比べ非線形連結要素を用いて滑り・ はく離の幾何学的非線形性を考虑することにより, 実験 結果とかなり良く一致するようになった。また動土圧時 刻歴では，受働側・主働側における土圧の非対称性等実 験で確認された現象が解析でも再現されていることが分 かる。

次に，全解析ケースに関して入力加速度の増加による 構造物模型頂部加速度の最大値の変化を実験結果ととも に図一17 に示す。実験結果と両解析結果はほぼ対応し ていることから，構造物の最大加速度を推定するだけで あれば，等価線形解析と非線形連結要素を用いた解析と 

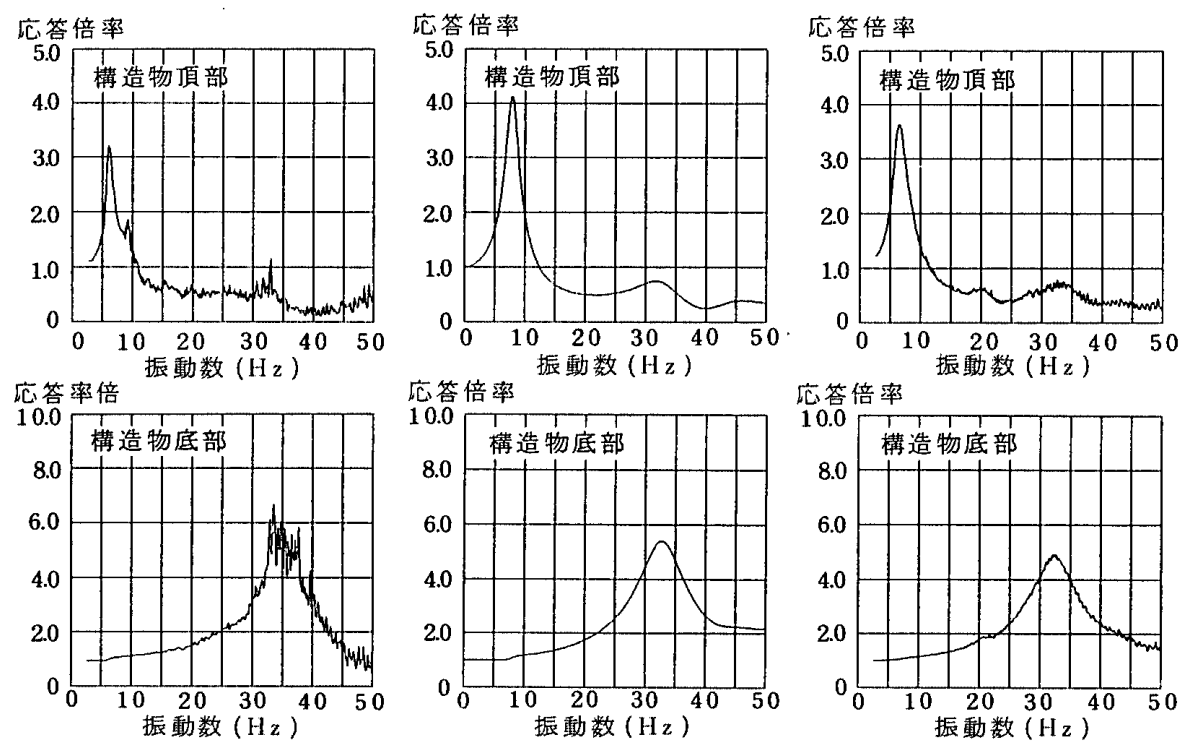

(a) 実験結果

(b) 等価線形解析結果

(c) 連結要嗉解析結果

図一16 振動台に対する構造物模型頂部ならびに底部加速度のフーリエ・スペクトル比 (埋め込み深さ $20 \mathrm{~cm}, 50 \mathrm{Gal}$ 加振)

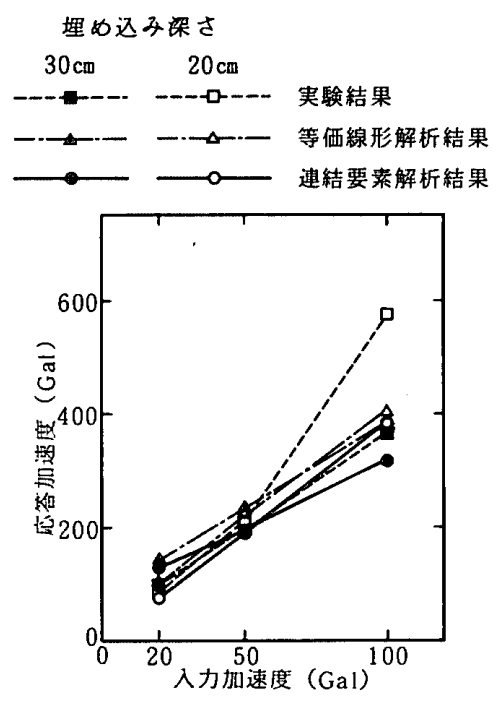

図一17 入力加速度と構造物模型頂部の 応答加速度最大值の関係

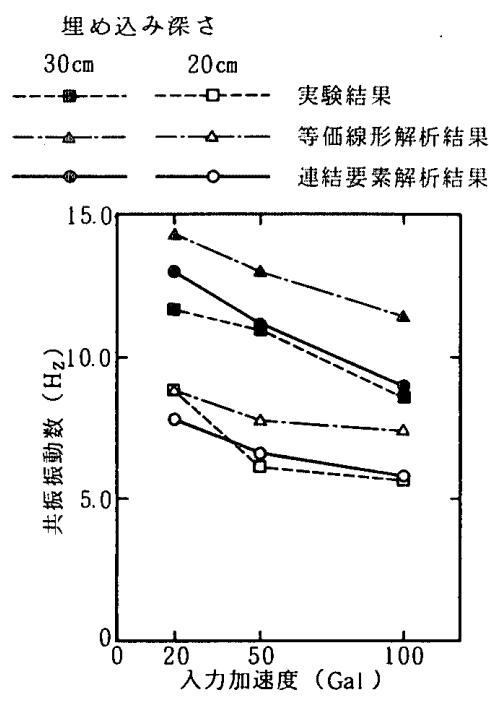

図一18 入力加速度と構造物模型の ロッキングが卓越する 1 次 共振振動数の関係

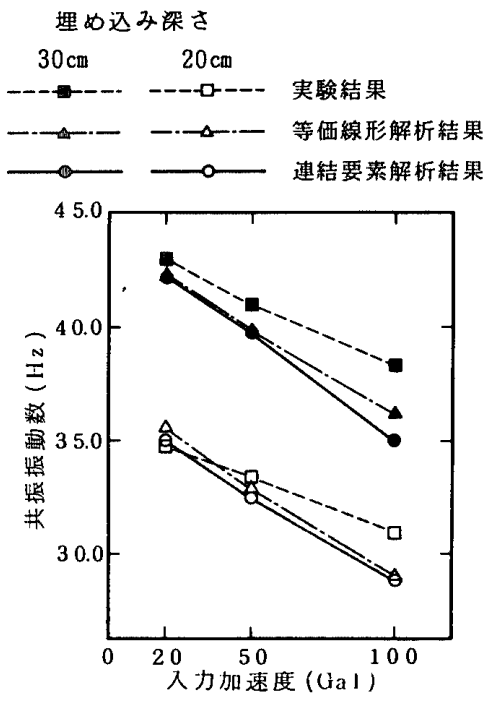

図一19 入力加速度と構造物模型 底部の動きが卓越する 2 次共振振動数の関係
で有意な差は認められないとの見方もできる。しかし， 図一18 に示す入力加速度と構造物模型のロッキングが 卓越する共振振動数の関係では, 前述の等価線形解析結 果は非線形連結要素を用いた解析結果や実験結果の振動 数よりかなり高くなっている傾向が確認できる。また， 図一19 に示す入力加速度と 2 次共振振動数の関係では, 両解析結果とも入力加速度の増加に対する共振振動数の 低下が実験結果と比較してやや顕著であるが，概略両解 析結果とも実験結果と対応しており，2次ピークのひず み・変位の範囲の地盤の涠性評価としては, 両解析で有 意な差はないと言う前述の傾向が確認できる。以上の結 果は, 等価線形解析には限界があり, 非線形連結要素を 用いた解析が有効であることを示している。
構造物模型側面の動土圧最大値分布を図一 20 に示す。 これらの図では，実験結果の最浅部 (GL-2. $5 \mathrm{~cm}$ 位置) の動土圧がすべてのケースで解析值より大きくなってい る。これは，側方地盤を振動によって締め固めた時，地 表付近は振動が大きく良く締め固まったこと，および構 造物模型近傍では構造物の振動によって地表付近の砂が もぐり込み特に強く締め固められたことにより，砂の剛 性が高くなっているためと考えられる。一方解析では, 側方地盤の魝性が拘束圧の 0.5 乗に比例する ((1) 式 参照）と仮定しているため，最浅部ではかなり小さな動 土圧を与えることになる。この部分を除いて実験結果の ばらつきの範囲を考慮すると, 動土圧の非対称性が最も 強い埋め込み深さ $20 \mathrm{~cm}, 50 \mathrm{Gal} \cdot 100 \mathrm{Gal}$ 加振を除け 


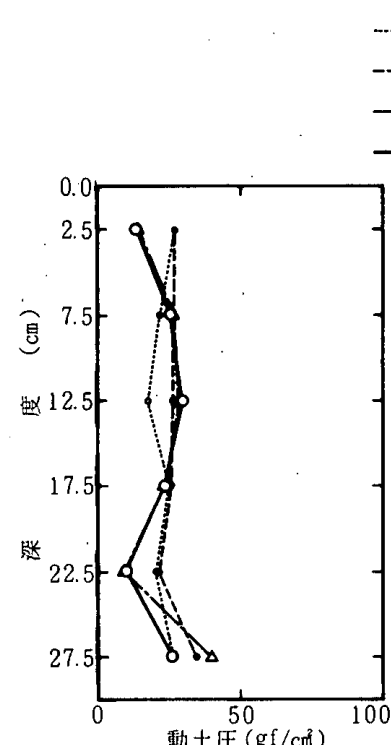

(a) $30 \mathrm{~cm}, 20 \mathrm{Gal}$

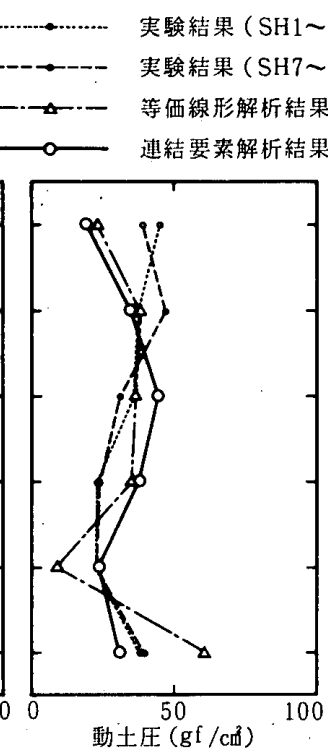

(b) $30 \mathrm{~cm}, 50 \mathrm{Gal}$

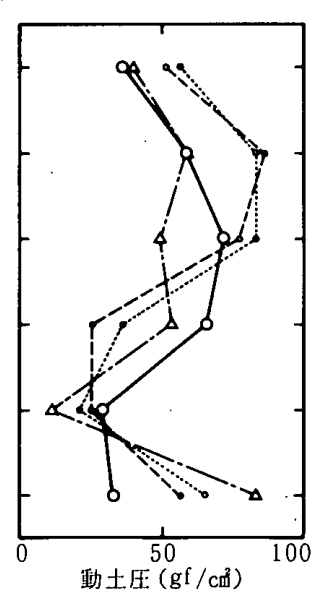

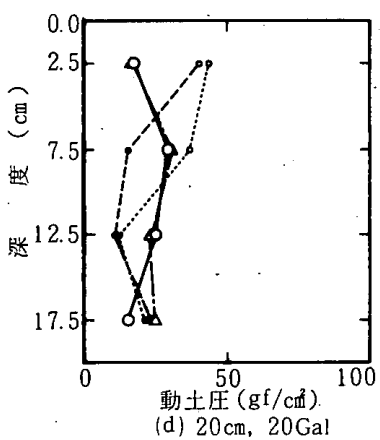
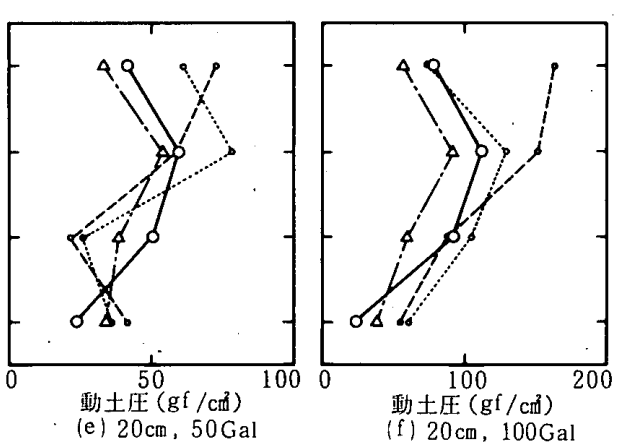

の非線形現象を検討するためにここの非 線形現象に焦点をあてた振動台による模 型実験を行った。この実験結果を基に， 材料非線形性を等価線形で扱い, 幾何学 的非線形性を非線形連結要素でモデル化 して, 両者の非線形現象を同時に扱い得 る 2 次元 FEM による動的解析手法を 提案した。この解析手法を用いて実験結 果のシミュレーションを行った。これら の実験と解析を通して以下のことが分 かった。

a) 振動台による模型実験の結果から, 非線形性を考慮する必要があることが実 験的に確認された。

b）実験から得られた構造物側面が受け る動土圧は，顕著な非対称性を示し，ひ ずみが大きい場合の履歴ループは三角形 の形状となった。特に主働側では早い段 階で降伏現象が見られ，解析的にはこれ をはく離点として扱い得る。

c）地盤の材料非線形性を等価線形で扱 い, 地盤亡構造物の接触部分の滑り・は <離の幾何学的非線形性を非線形連結要 素でモデル化した解析手法を提案した。

d）振動台による模型実験のシミュレー ションを行い, 本解析手法の妥当性を検 討し, 構造物模型の加速度応答倍率, 共振振動数, 動土 圧時刻歴なごの諸応答量に関して実験結果と整合する結 果が得られた。シミュレーションが2 次元モデルである ことや, 実験・解析ともに有限領域のものであるという 制約はあるが, 本解析手法の精度・信頼性が確認された。

本解析手法は，適用範囲として周辺地盤の剛性低下率 で $1 / 10$ 程度までカバーしているため, 軟弱地盤に建設 される一般構造物や塔状構造物等の設計に広く利用でき るものと思われる。

\section{謝 辞}

本論文は既発表文献 201 24)を中心に加筆したものであ ば，両解析結果は実験結果と比較的傾向が合っていると 言える。しかし，埋め込み梁さ $20 \mathrm{~cm}, 50 \mathrm{Gal} \cdot 100 \mathrm{Gal}$ 加振では等価線形解析結果の土圧は実験結果に比べて小 さくなる。

解析結果の各要素のひずみ範囲を図一21に示す。剛 性低下率で 0.1 程度になっている要素が存在しているに もかかわらず，解析結果が実験結果と比較的傾向が合っ ていたことは，この解析手法の適用範囲が相当に広いこ とを示している。

\section{5. 結 論}

大地震時に生じると考えられる地盤一構造物相互作用

るが,これらの内容のうち, 実験およびシミ゙ュレーショ ンの一部は, 6 電力 (東京・東北・中部・北陸・中国 日本原子力発電) と鹿島建設 (株) との共同研究「原子 炉建屋の地震時安定性に関する研究」で実施されたもの である。本研究では, 電力共通研究の幹事である東京電 力 (株) 矢野明義氏をはじめとする各電力の方々にご指 導をいただきました。梁く感謝いたします。

なお, 本研究のシミュレーションを行うにあたり, 鹿 島建設 (株) 構造設計部藤本信夫氏に御協力をいただい た。また，本論文をまとめるにあたり鹿島建設（株）技 術研究所津川恒久氏に貴重なご助言をいただいた。感謝 
の意を表します。

\section{参考文献}

1）たと之ば，原 昭夫，清田芳治，大崎順彦：地盤振動解 析のための土の動力学モデルの提案と解析例, 第 5 回日 本地震工学シンポジウム, pp.697 704, 昭和 53 年 11 月

2) Per B. Schnabel, John Lysmer and H. Bolton Seed: SHAKE-A Computer Program for Earthquake Response Analysis of Horizontally Layered Sites, EERC 72-12 (Univ, of California - Barkeley), 1972.12

3) John Lysmer et al. : FLUSH-A Computer Program for Approximate 3-D Analysis of Soil-Structure Interaction Problems, EERC 75-30 (Univ. of California - Berkeley), 1975.11

4）原 昭夫，清田芳治：組み合せ応力下における土の非線 形解析手法, 鹿島建設技術研究所年報, 第 32 号, pp. 125 $\sim 128$, 昭和 59 年 6 月

5) D.K. Vaughan and J. Isenberg: Soil-Structure Interaction in Explosive Testing of Model Containments, Nuclear Engineering and Design 77, pp.229 250, 1984

6) Goodman, R.E. : Methods of Geological Engineering in Discontinuous Rocks, West Publishing Company, ch.8, pp. $300 \sim 368,1976$

7）土岐憲三，佐藤忠信，三浦房紀：強震時における地盤と 構造物の間の剝離と滑動, 土木学会論文報告集, 第 302 号, pp. $31 \sim 41,1980.10$

8）渡辺啓行，杤木 均：すべり剝離を伴う基礎・地盤の動 的相互作用に関する模型振動実験と数値シミュレーショ ン, 土木学会論文集, 第 368 号 / I -5, pp. 319 327, 1986.4

9）原 昭夫, 内藤幸雄, 堀越清梘, 藤本信夫：建屋と地盤 間の浮き上がり・剩離・すべりを考慮した動的解析，鹿 島建設技術研究所年報，第 33 号，pp.139 144，昭和 60 年 6 月

10）矢野明義, 原 昭夫ほか 6 名：建屋浮き上がりに関する 静的・動的実験と解析（その $1 \sim$ その 3 ）, 日本建築学会 大会学術講演梗概集, pp.165 170, 昭和 60 年 10 月

11）矢野明義, 内藤幸雄, 堀越清視：非線形連結要素 FEM モデルによる基礎浮き上がり動的解析，日本建築学会構 造系論文報告集, No.427, pp.87～98，1991 年 9 月

12）土岐䝴三，三浦房紀：地盤一構造物系の非線形地震応答解 析, 土木学会論文報告集, 第 317 号, pp.61 68, 1982.1

13）矢野明義, 原 昭夫ほか 5 名：埋め土・浮き上がり非線 形に着目した地盤建屋模型の振動台実験とその解析（そ
の 1 一 その 4), 日本建築学会大会学術講演梗概集, pp. 689 695, 昭和 59 年 10 月

14) N. Norby Nielsen : Steady-state versus Rundown Tests of Structures, ASCE, ST 6, pp.51 64, 1964.12

15）矢野明義，原 昭夫，清田芳治：模型土構造物の振動実 験のための基礎的研究一その 2 土の圧縮・引張り变形 特性一, 日本建築学会大会学術講演梗概集, pp.599 600, 昭和 56 年 10 月

16）内藤幸雄：等価線形 FEM の適用に関する考察，日本建 筑学会構造系論文報告集，第 368 号，pp. $57 \sim 66$, 昭和 61 年 10 月

17) Drnevich, V.P. and Richart, F.E. : Dynamic Prestraining of Dry Sand, Proc. ASCE, Vol.96, SM 2, pp.453 469, 1970.3

18）原 昭夫, 清田芳治：大型動的せん断試験装置による土 の動的変形特性（その 2 ）砂の動的せん断変形特性值の 上載応力依存性, 第 19 回土質工学研究発表会, pp.581 582 , 昭和 59 年 6 月

19) Tatsuoka F. and Haibara O. : Shear Resistance between Sand and Smooth or Lubricated Surface, Soils and Foundations, Vol.25, No.1, pp.89 98, 1985.3

20）矢野明義, 原 昭夫, 内藤幸雄, 鈴木康嗣, 堀越清視, 藤本信夫：埋め士・浮き上がり非線形に着目した地盤建 屋模型の振動台実験とその解析（その5その 6), 日本 建築学会大会学術講演梗概集, pp.171 174, 昭和 60 年 10 月

21）矢野明義, 原 昭夫, 堀越清視, 内藤幸雄, 藤本信夫, 鈴木康嗣：埋め込みを有する建屋の強震時非線形応答に 関する実験および解析（その1〜その2）, 日本建築学会 大会学術講演梗概集, pp.509 512, 昭和 61 年 8 月

22）原 昭夫, 堀越清視, 内藤幸雄, 鈴木康嘼, 藤本信夫： 埋め込みを有する建屋の地震時土圧に関する実験と解析, 第 22 回土翼工学研究発表会, pp.705 708, 昭和 62 年 6 月

23）原 昭夫, 堀越清視, 内藤幸雄, 藤本信夫, 鈴木康嗣： 地下壁と地盤の滑り・はく離が埋め込み建屋の動的応答 におよぼす影響，日本建築学会大会学術講演梗概集， pp.565 566，昭和 62 年 10 月

24）原 昭夫, 堀越清視, 内藤幸雄, 藤本信夫, 鉿木康嗣： 埋め込みを有する建屋の非線形忍答に関する振動台実験 とその解析，鹿島建設技術研究所年報，第 35 号, pp.135 $\sim 142$, 昭和 62 年 6 月

(1992 年 1 月 10 日原稿受理, 1992 年 5 月 12 日採用決定） 